Penelitian

\title{
Deteksi Kebuntingan Dini pada Sapi Perah dengan Pemeriksaan Ultrasnography (USG) dan Analisis Hormon Steroid
}

\author{
(Early Pregnancy Detection using Ultrasonography detection and \\ Hormone Steroid Analysis in Dairy Cattle) \\ Dilla Frastantie', Muhammad Agil², Ligaya ITA Tumbelaka² \\ ${ }^{1}$ Program Studi Biologi Reproduksi Sekolah Pascasarjana Institut Pertanian Bogor, Bogor, Indonesia \\ ${ }^{2}$ Departemen Klinik, Reproduksi, dan Patologi Fakultas Kedokteran Hewan Institut Pertanian Bogor, Bogor, Indonesia \\ *Penulis untuk korespondensi: ligaya290212@gmail.com \\ Diterima 5 September 2018, Disetujui 29 Juni 2019
}

\begin{abstract}
ABSTRAK
Penelitian ini bertujuan untuk mengetahui efektivitas metode deteksi kebuntingan dini menggunakan ultrasonography (USG) dan pemeriksaan steroid (progesteron dan estrogen) pada sapi. Sebanyak sepuluh ekor sapi diperiksa di peternakan sapi perah Kawasan Usaha Peternakan Cibungbulang, Bogor. Lima ekor dideteksi bunting dini dan lima ekor tidak bunting. Pengambilan plasma darah dilakukan empat hari sekali dimulai dari 40 hari sebelum pelaksaan IB sampai 30 hari untuk sapi tidak bunting hingga hari ke-6o bila sapi bunting. Pemeriksaan dengan USG dilakukan menggunakan probe $5 \mathrm{MHz}$ dimulai sejak hari ke-9 pasca IB bersamaan dengan pengambilan sampel darah. Hasil USG menunjukkan keberadaan konseptual vesikel pada hari ke-15 setelah IB dengan diameter $0,44 \mathrm{~cm}$. Embrio dapat dideteksi mulai hari ke-26 dengan ukuran $2,6 \mathrm{~cm}$. Konsentrasi progesteron pada saat IB (baseline) adalah 6-8 ng/ml dan meningkat menjadi 30-50 ng/ml pada hari ke-15 pasca IB. Konsentrasi progesteron terus bertahan tinggi sejak hari ke-15 sampai hari ke-60 pasca IB. Dapat disimpulkan bahwa penggunaan USG dapat mendeteksi kebuntingan lebih dini dibandingkan dengan pemeriksaan hormonal.
\end{abstract}

Kata kunci: kebuntingan dini, ultrasonografi, analisa progesteron, sapi perah

\begin{abstract}
The aim of this study was to find out a methodefor early pregnancy detection in dairy cows.Two methode were used in this study, Ultrasonography methode (USG) and plasma progesterone and estrogen concentration analysis using ELISA. Ten dairy cows from Kawasan Usaha Peternakan Cibungbulang, Bogor were used in this study. Five were pregnant and 5 were not pregnant cows. Blood samples, in 4 days interval, were taken from 40 days before artificial insemination (Al) and, 30 days after Al for non pregnat cows and 60 days after Al for prenant cows. In addition, USG using $5 \mathrm{MHz}$ probewere also taken starting at day 9 after $\mathrm{Al}$ and at the same time with blood sample colection. The result of USG showed that the presence of the conceptus vesicle with $0,44 \mathrm{~cm}$ diameter was detected as early as day 15 after Al. At 26 days, embryo can be detected with the size of 2,6 cm. Progesteron concentration showed that at the time oflA was $6-8 \mathrm{ng} / \mathrm{mL}$, increased to $30-50 \mathrm{ng} / \mathrm{mL}$ at day 15 after Al and remain high until day 60. In conclusion, using USG could detect pregnancy erlier than progesterone concentration analysis.
\end{abstract}

Keywords: early pregnancy, ultrasound, analysis progesterone, dairy cows 


\section{PENDAHULUAN}

Keberhasilan reproduksi pada pemeliharaan ternak sapi perah, dapat dinilai dari sapi betina yang dapat melahirkan seekor anak setiap tahunnya. Peningkatan produktivitas sapi perah dapat dicapai dengan pengelolaan pakan dan evaluasi reproduksi. Evaluasi reproduksi dapat dilakukan dengan pemeriksaan kebuntingan dini pasca perkawinan alam maupun dengan inseminasi buatan (IB) yang akan membantu peternakan dalam memperoleh sapi betina yang mampu melahirkan satu anak setiap tahunnya. Menurut Sajuti (2011) akurasi metoda diagnosis kebuntingan dengan rentang waktu yang singkat, dapat menghindari kerugian waktu peternak dalam pemeliharaan sapinya karena tidak terdeteksinya kematian embrio dini. Pada penelitian Ayalon (1978) dan Stevenson (2001), menyatakan bahwa kematian embrio dini dan tahap lanjut dapat terjadi antara hari ke- 5-40 setelah IB, serta hari ke28-56 sebanyak 43\% (El-Zarkouny et al. 2000). Apabila kematian embrio dini tidak dapat dideteksi dengan cepat, hal ini akan sangat merugikan peternak. Oleh sebab itu, deteksi kebuntingan dini merupakan komponen penting untuk menekan biaya produksi yang tinggi (Pereira et al. 2013).

Beberapa metode diagnosis kebuntingan pada sapi perah yang telah dilakukan antara lain eksplorasi rektal pada kebuntingan usia dini (Romano et al. 2006), USG untuk mengamati aliran darah pada corpus luteum ( $\mathrm{CL}$ ), ukuran $\mathrm{CL}$ dan tekstur dari uterus (Scully et al. 2014), progesteron assay untuk mengamati pengaruh progesteron terhadap perubahan endometrium (Forde et al. 2011), analisis progesteron pada susu (Markusfeld et al.1990; Oltenacu et al.1990). Analisis kebuntingan menggunakan hormon progesteron dapat dilakukan dengan teknik enzyme linked-immunosorbent assay (ELISA) (Green et al.2005) dan Radio Immuno Assay (RIA) (Tjiptosumirat 2009). Penggunaan RIA bersifat radioaktif, sementara ELISA menggunakan reaksi enzymatis, sehingga lebih aman dilakukan. Sampai saat ini sangat sulit dijumpai literatur tentang diagnosa kebuntingan dini menggunakan USG dan analisis hormon dengan teknik ELISA pada sapi perah di Indonesia, karena itu perlu adanya penelitian yang mengkaji efektivitas teknik ini.

\section{BAHAN DAN METODE}

\section{Hewan Penelitian}

Sebanyak sepuluh ekor sapi perah di peternakan sapi perah Kawasan Usaha Peternakan Cibung- bulang, Bogor digunakan. Lima ekor sapi dideteksi bunting dan lima ekor sapi tidak bunting. Pemberiaan pakan rumput atau hijauan pada pagi dan sore hari sebanyak $10 \%$ dari bobot badan dan air minum secara ad libitum. Sapi penelitian pernah bunting (laktasi ke-2-4), berumur 3-5 tahun, memiliki kualifikasi tubuh yang sehat dan sehat reproduksinya dan dengan Body Condition Score (BCS) 2,53,0 skala 1-5 (Ferguson et al. 1994). Sapi dikandangkan dalam kendang komunal. Perkawinan sapi dilakukan oleh inseminator yang kompeten.

\section{Pemeriksaan kebuntingan dengan Ultrasonografi (USG)}

Pencitraan ultrasonografi secara transrektal mengunakan alat ultrasonografi 4VetMini dan i-Scan (Draminski, PT Agroprima Lab Indonesia). Pada tahap awal, dilakukan penyiapan perangkat USG. Transduser yang digunakan jenis linier dengan frekuensi 5.0 MHz. Selanjutnya feses dikeluarkan dari rektum sapi, kemudian dilakukan eksporasi manual dari topografi trakus reproduksi sapi sebelum dilakukan USG. Kemudiantransduser dan glove diberi gel untuk memudahkan dalam memasukkan transduser kedalam rektum agar tidak mengiritasi mukosa rektum dan untuk mendapatkan gambaran USG yang baik. Pemeriksaan ini dilakukan selama sapi berdiri. Selama berada di dalam, rektum probe diarahkan ke tanduk uterus dan ovarium, yaitu bagian ventral rektum menyusuri trakus reproduksi. Uterus terlihat pada bagian ventral rektum, di atas kandung kemih. Kornua uterus akan terlihat dalam keadaan potongan melintang ketika transduser digerakkan kearah lateral. Pada monitor USG, vesikel urinaria, cairan embrionik, dan lumen uterus terlihat sebagai suatu gambaran anechoic (gelap), pada vesikel urinaria besar nya dengan ukuran yang beragam tergantung pada volume urin yang disimpan. Mukosa dan organ digambarkan sebagai suatu permukaan hypoechoic (abu-abu) yang bergelombang. Sedangkan hyperechoic (putih) merupakan citra dari tulang dan otot yang padat. Status kebuntingan dari tampilan citra ultrasonografi didokumentasikan dan disimpan dalam format JPEG untuk dianalisa ukuran vesika embrionik dan ukuran embrio hingga fetus lebih lanjut menggunakan program Image J.

\section{Analisis Hormon}

Pengambilan sampel darah pada semua sapi penelitian pada waktu siklus dan selama bunting 60 hari, melalui vena coccygeae (ekor), menggunakan vacutainer tube mengandung antikoagulan K3 EDTA 
$1.8 \mathrm{mg} / \mathrm{mL}$ (Disposable Evacuated Blood Collection Tubes, Zhejiang U-REAL Medical Tecnology Co. Ltd). Pengambilan darah dilakukan setiap empat hari sekali. Volume darah yang diambil sebanyak $3 \mathrm{ml}$. Pengambilan sampel darah dan alur penelitian ditampilkan pada Gambar 1. Transportasi sampel darah ke laboratorium hormon dalam icebox. Sampel darah disentrifuga dengan kecepatan 1500-2000 G selama 10 menit untuk memperoleh plasma. Plasma yang diperoleh disimpan dalam tabung microtube $2 \mathrm{Ml}$ dengan suhu $-20^{\circ} \mathrm{C}$ sampai dilakukan analisis konsentrasi hormon progesteron dan estradiol menggunakan kit ELISA komersial.

\section{HASIL PENELITIAN}

\section{Citra USG Sapi Tidak Bunting}

Secara umum, USG dilakukan pada semua sapi dalam penelitian ini. Apabila sapi tersebut tidak bunting maka pengambilan darah dan pemeriksaan USC dilakukan sampai hari ke-30 pasca IB. Gambaran
USG sapi tidak bunting dapat dilhat pada Gambar 2. Pencitraan uterus menunjukan tetap kompak pada hari ke-10 hingga hari ke-29.

Gambaran citra uterus sapi tidak bunting walaupun yang telah di IB nampak kompak tanpa adanya konseptual vesikel, uterus berwarna lebih hypoechoic (abu-abu) dibandingkan dengan area disekitarnya. Perbedaan antara uterus dengan otot yang berwarna lebih hyperechoic (putih) terlihat jelas (Gambar 2). Curran et al. (1986) menemukan konseptual vesikel pada hari ke-20 yang terus berkembang hingga hari ke-60. Gambaran konseptual vesikel diuterus dengan USG akan tampak berupa kantong dengan warna anechoic. Hasil penelitian pada sapi ini konseptual vesikel sampai pemeriksaan hari ke-29 tidak ditemukan, maka sapi tersebut dapat dinyatakan sapi tidak bunting.

\section{Citra USG Sapi Bunting}

Dari sepuluh ekor sapi penelitian, lima ekor sapi didiagnosis bunting menggunakan USG, maka sapi ini diikuti kebuntingannya hingga hari ke-60.

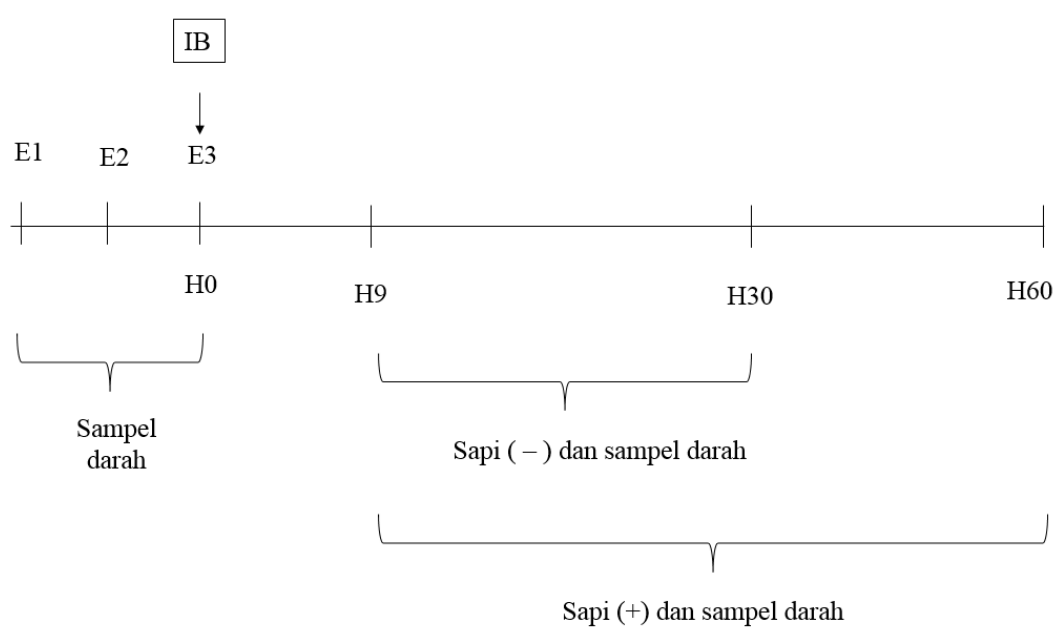

Gambar 1 Alur Penelitian dan pengambilan sampel darah
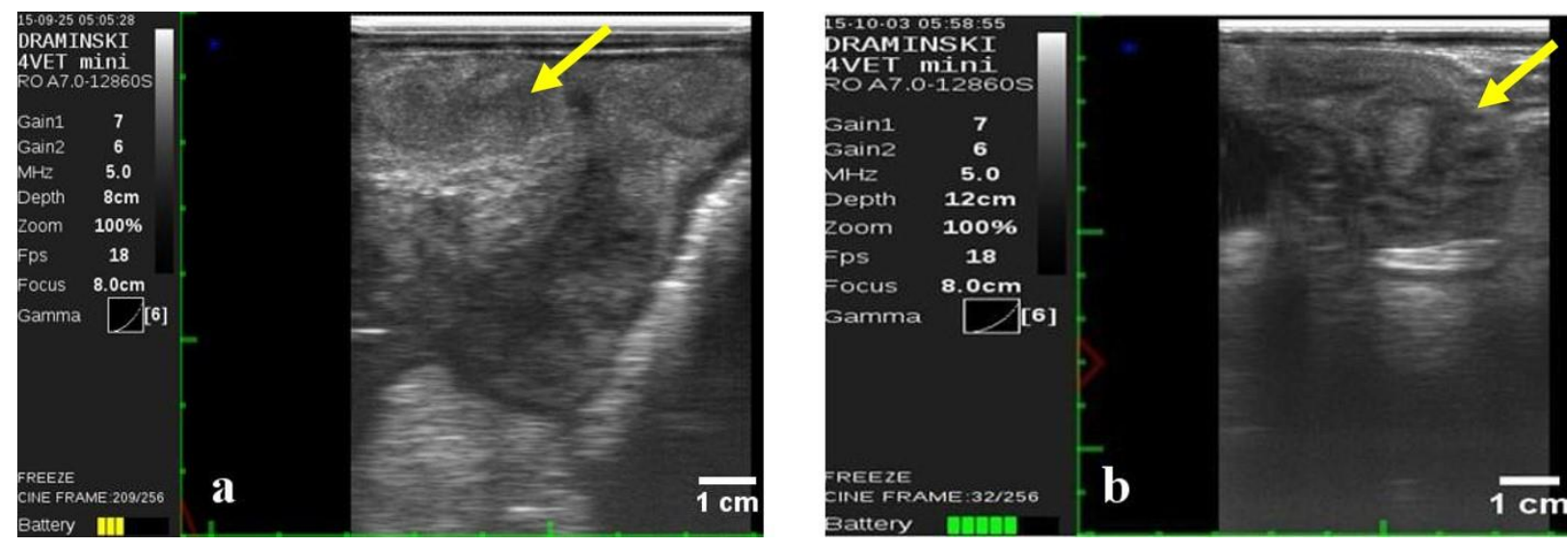

Gambar 2 a. Uterus hari ke-10; b. Uterus hari ke-29 

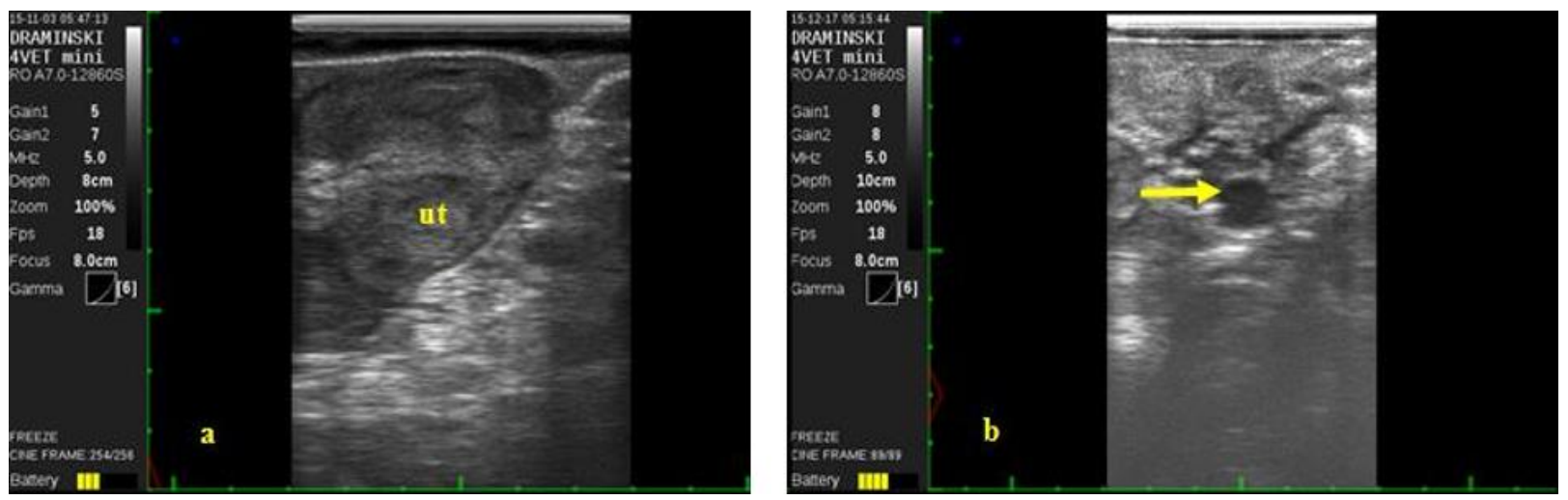

Gambar 3 Citra uterus 15 hari pasca perkawinan. a. Sapi tidak bunting, b. Sapi bunting (anak panah menunjukkan adanya konseptual vesikel)

Hasil penelitian menunjukkan, diagnosa kebuntingan dini terdeteksi pada hari ke-15 dengan pencitraan ultrasonografi pada uterus tampak keberadaan konseptual vesikel.

Gambaran citra uterus sapi tidak bunting pada Gambar 3a. Pada Gambar 3b, menunjukan gambaran USG dengan konseptual vesikel yang berwarna anechoic yang ditunjuk anak panah, gambaran inilah yang menunjukkan bahwa sapi betina tersebut bunting. Karena kebuntingan terdeteksi pada hari ke-15 setelah IB maka dapat dinyatakan sebagai kebuntingan dini. Posisi kantong yang berisi cairan amnion, sama seperti penelitian Curran et al. (1986), terletak ipsilateral terhadap korpus luteum di salah satu kornua uteri. Hasil serupa diperoleh Beal et al. (1992) yakni konseptual vesikel ditemukan pada hari ke-19 setelah IB. Ukuran konseptual vesikel ini akan terus meningkat seiring dengan waktu diikuti dengan peningkatan cairan yang ada di dalamnya. Hasil gambaran USG memperlihatkan perbedaan ukuran diameter vesika konseptual mulai antara hari ke-15 dan hari ke-19 (Gambar 4). Pada hari tersebut diameter ukuran

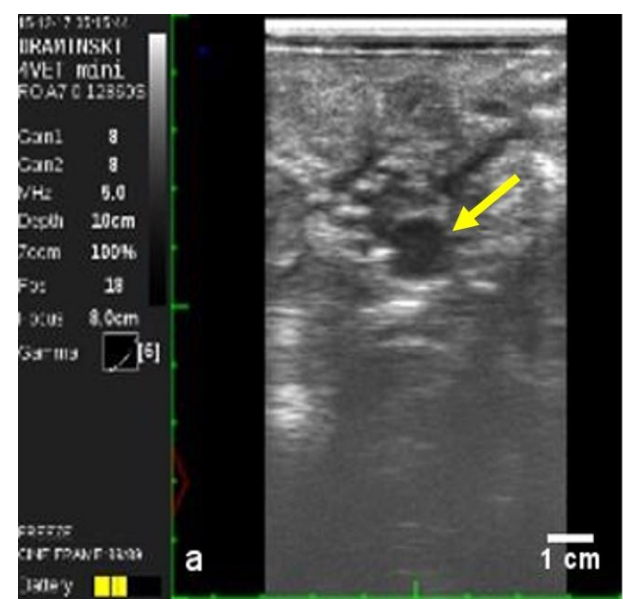

vesika konseptual masih dapat diukur. Pada hari ke26 dan seterusnya, diameter vesika konseptual sudah tidak dapat lagi diukur. Hal ini akibat dari peningkatan ukuran dan volume cairan embrionik pada vesikel embrio. Namun, Kähn and Volkmann (2004) menyatakan bahwa ada hari ke-25 sampai hari ke-30, kantong amnion berada pada ukuran maksimal dengan diameter $10 \mathrm{~mm}$.

\section{PEMBAHASAN}

Pada penelitian ini, diameter vesika konseptual lebih dari $4 \mathrm{~mm}$ sulit untuk di deteksi dengan menggunakan probe USG dengan frekuensi $5 \mathrm{MHZ}$. Sesuai dengan penelitian Pierson dan Ginther (1984), diameter kantong amnion yang masih sangat kecil yakni sekitar 2 sampai $4 \mathrm{~mm}$ yang dapat dideteksi dengan USG frekuensi di atas $5 \mathrm{MHz}$. Pada penelitian ini konseptual vesikel terdeteksi paling awal pada hari ke-15 setelah IB dengan ukuran diameter 0,44 mm (Gambar 4a.). Waktu ini cukup dekat dengan kemungkinan implantasi embrio pada uterus pada hari ke-7 - 9 pasca IB.

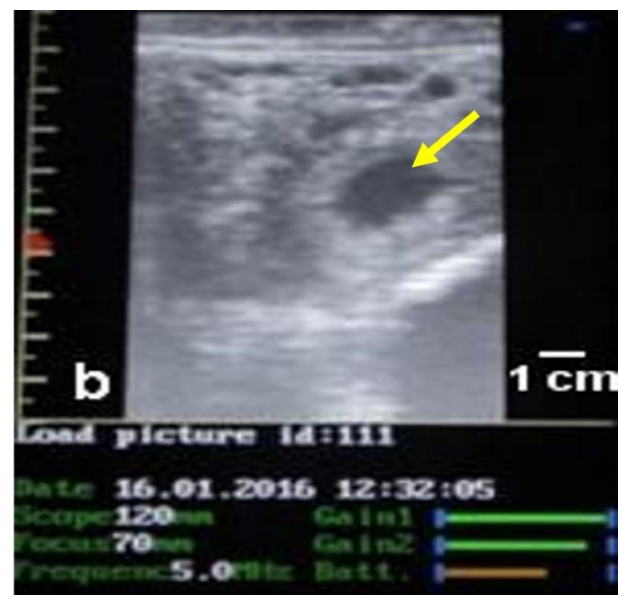

Gambar 4 Citra USG konseptual vesikel a. Hari ke-15 ; b. Hari ke-19 
Diameter konseptual vesikel terus bertambah seiring waktu hingga pada hari ke-19 menjadi 0,91 $\mathrm{cm}$. Karena kemampuan alat USG mengukur diameter vesika konseptual hanya mencapai ukuran diameter $0,4 \mathrm{~mm}$, peningkatan ukuran vesikel membuat area pencitraan selanjutnya semakin sempit, sehingga pada hari berikutnya hanya terdapat citra anechoic atau hitam seperti lumen. Menurut Curran et al. (1986), konseptual vesikel terus meningkat secara linier sejak hari ke-20 hinga hari ke-6o kebuntingan. Peningkatan ini akan terus berlangsung, sampai pada taraf muncul embrio yang akan terlihat sebagai struktur hypoechoic dalam cairan tersebut. Kemudian strukturnya akan semakin jelas, hingga akan terlihat membran embrio bersama dengan embrio.

Hasil pemeriksaan pada hari ke-26 kebuntingan, terdapat embrio yang menempel didinding uterus, terlihat di layar USC sebagai struktur hypoechoic dengan warna abu-abu dan berukuran $1,8 \mathrm{~cm}$ (Gambar 5a). Pada gambar terlihat adanya penebalan pada satu sisi dinding uterus. Pada hari ke-30, embrio berukuran 1,05 $\mathrm{cm}$ dan sudah nampak detak jantungnya. Hasil USG dengan gambaran tersebut dapat diyakinkan bahwa pasti adanya embrio atau terjadi kebuntigan.

Hari ke-37 kebuntingan, ukuran embrio $1,93 \mathrm{~cm}$ dan posisi embrio sudah mulai dapat berubahubah. Pada hari ke-45 ukuran embrio telah men- capai 3,93 cm, dimana proses diferensiasi mulai terlihat, yaitu dengan ditemukannya nya tonjolan yang akan menjadi bakal kaki depan dan kaki belakang sehingga fase ini disebut fetus. Pada usia hari ke-52 ukuran fetus telah mencapai $4,75 \mathrm{~cm}$, hingga dapat terlihat jelas bentuk tulang rusuk dan tulang belakang dengan warna yang hyperechoic (putih) pada layar USG. Gambar ini hanya dapat dianalisis hingga kebuntingan hari ke-52, sebab pada hari selanjutnya hingga hari ke-60, fetus sudah bergerak bebas dan tidak menetap pada satu area uterus. Namun, dapat terlihat citra organ dan rangka, yang menunjukkan perkembangan secara spesifik alat gerak maupun tulang pada tubuh. Sesuai dengan gambar diatas, citra tulang ditunjukkan dengan warna yang lebih hyperechoic dibandingkan dengan citra organ yang lain.

\section{Gambaran Konsentrasi Hormon Progesteron dan Estrogen}

Hasil analisis hormon menunjukan konsentrasi progesteron tetap tinggi pada sapi yang bunting dan cenderung meningkat dibandingkan konsentrasi progesterone pada saat fase luteal ketika bersiklus. Hal ini sesuai dengan hasil penelitian Wijono (1998), bahwa kadar progesteron pada sapi madura yang fluktuatif namun teratur pada fase luteal (siklus estrus), dan terus meningkat ketika sapi tersebut bunting (Simersky et al. 2007).
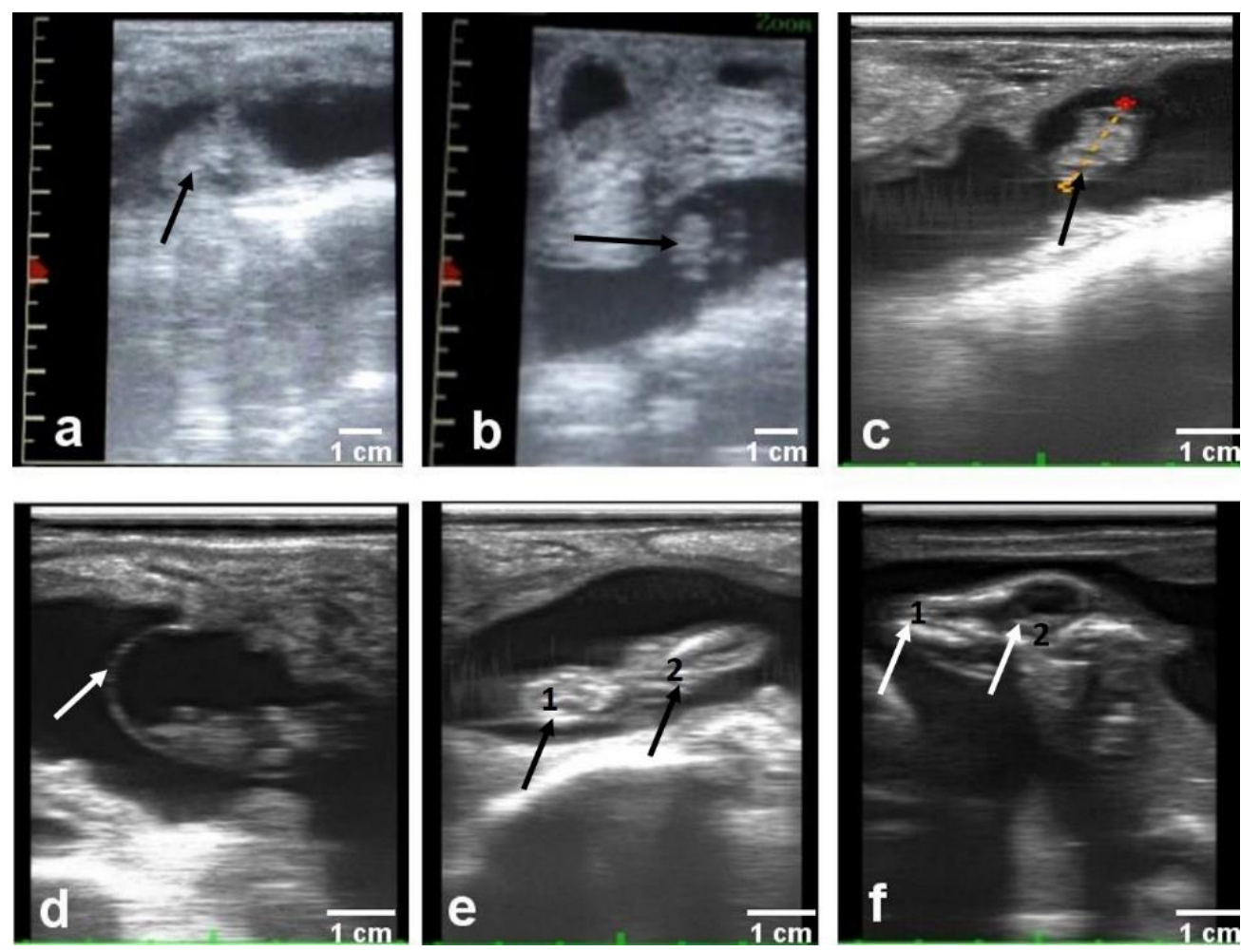

Gambar 5 a. Hari ke-26, b. Hari ke-30, c. Hari ke-37, d. Hari ke -45 e : Hari ke-52, f. Hari ke-60 
Grafik pada Gambar 6 menunjukan bahwa gambaran konsentrasi estrogen $\left(E_{2}\right)$ pada sapi siklik maupun kebuntingan sampai hari ke-60 tidak menunjukan perbedaan yang nyata. Berbeda dengan gambaran konsentrasi progesterone $\left(P_{4}\right)$. Hasil pemeriksaan $\mathrm{P}_{4}$ menunjukan konsentrasi yang berbeda selama dua siklus es-trus sebelum sapi tesebut dinyatakan bunting. Pada setiap siklus estrusnya, tampak jelas peningkatan dan penurunan konsentrasi $\mathrm{P}_{4}$, sebanyak $6 \mathrm{ng} / \mathrm{mL}$ merupakan konsentrasi terendah $\mathrm{P}_{4}$ yang menunjukkan sapi masuk dalam periode estrus.

Pada hari ke- 6 periode metestrus konsentrasi $P_{4}$ meningkat secara signifikanmenjadi $32 \mathrm{ng} / \mathrm{mL}$. Pada saat sapi estrus dilakukan IB, pada hari ke-12 setelah IB konsentrasi $\mathrm{P}_{4}$ meningkat hingga pada puncak tertinggi pada hari ke-26 sampai hari ke-30 pasca IB dengan konsentrasi $50 \mathrm{ng} / \mathrm{mL}$. Pada hari tersebut sesuai dengan hasil dari citra USG, di dalam uterus telah di-temukan embrio dan pada kebuntingan hari ke-30, serta ditemukan juga detak jantung pada embrio tersebut.

Gambar 7 menunjukkan bahwa konsentrasi progesteron akan tetap bertahan tinggi untuk mempertahankan kebuntingan, meskipun pada awal kebuntingan konsentrasinya masih bersifat fluktuatif atau tidak stabil, namun konsentrasi tersebut tidak pernah turun hingga mencapai $6 \mathrm{ng} / \mathrm{mL}$ seperti pada saat sapi tersebut di IB atau masa estrus. Hal ini terjadi karena corpus luteum dipertahankan untuk memproduksi hormon progesteron hingga nanti nya akan dibantu dengan keberadaan plasentom yang membantu kerja corpus luteum, pada fase ini lah merupakan fase kritis terjadi kematian embrio dini. Menurut Vanroose et al. (2000), plasentom terbentuk pada hari ke-21-22 hari, sehingga fase dibawah 60 hari kebuntingan adalah fase yang sangat kritis bagi sapi untuk terjadi kematian embrio dini bahkan abortus. Oleh sebab itu, mengetahui sejak dini kebuntingan pada sapi sangatlah penting, agar peternak dapat memberikan treatment yang tepat kepada ternaknya yang telah bunting.

Deteksi kebuntingan dengan citra USG pada sapi perah dapat didiagnosa pada hari ke-15 pasca IB dengan adanya vesikel konseptual atau kantong kebuntingan. Konsentrasi hormon progesteron sampai hari ke-60 pasca IB masih sama dengan kisaran konsentrasi pada fase luteal yang menandakan hewan positif bunting. Oleh karena itu, penggunaan citra USG dapat digunakan untuk mendeteksi kebuntingan lebih dini dibandingkan dengan pemeriksaan hormonal.

\section{UCAPAN TERIMA KASIH}

Ucapan terima kasih disampaikan kepada para peternak sapi perah Kawasan Usaha Peternakan (KUNAK) Cibungbulang Bogor atas kerjasamanya

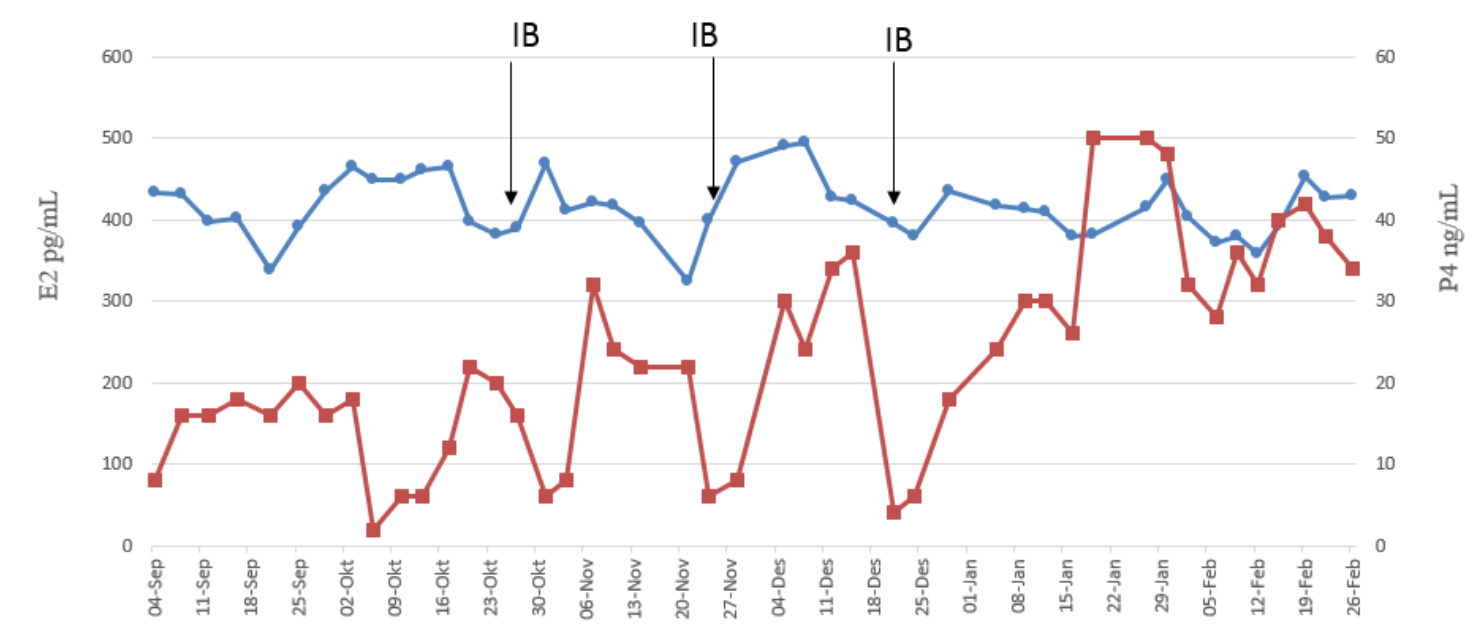

LEGENDA

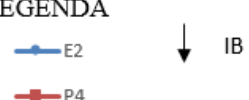

HARI PENGAMBILAN SAMPEL

Gambar 6 Gambaran hormon esterogen dan progesteron sapi \#1620 siklus dan bunting 


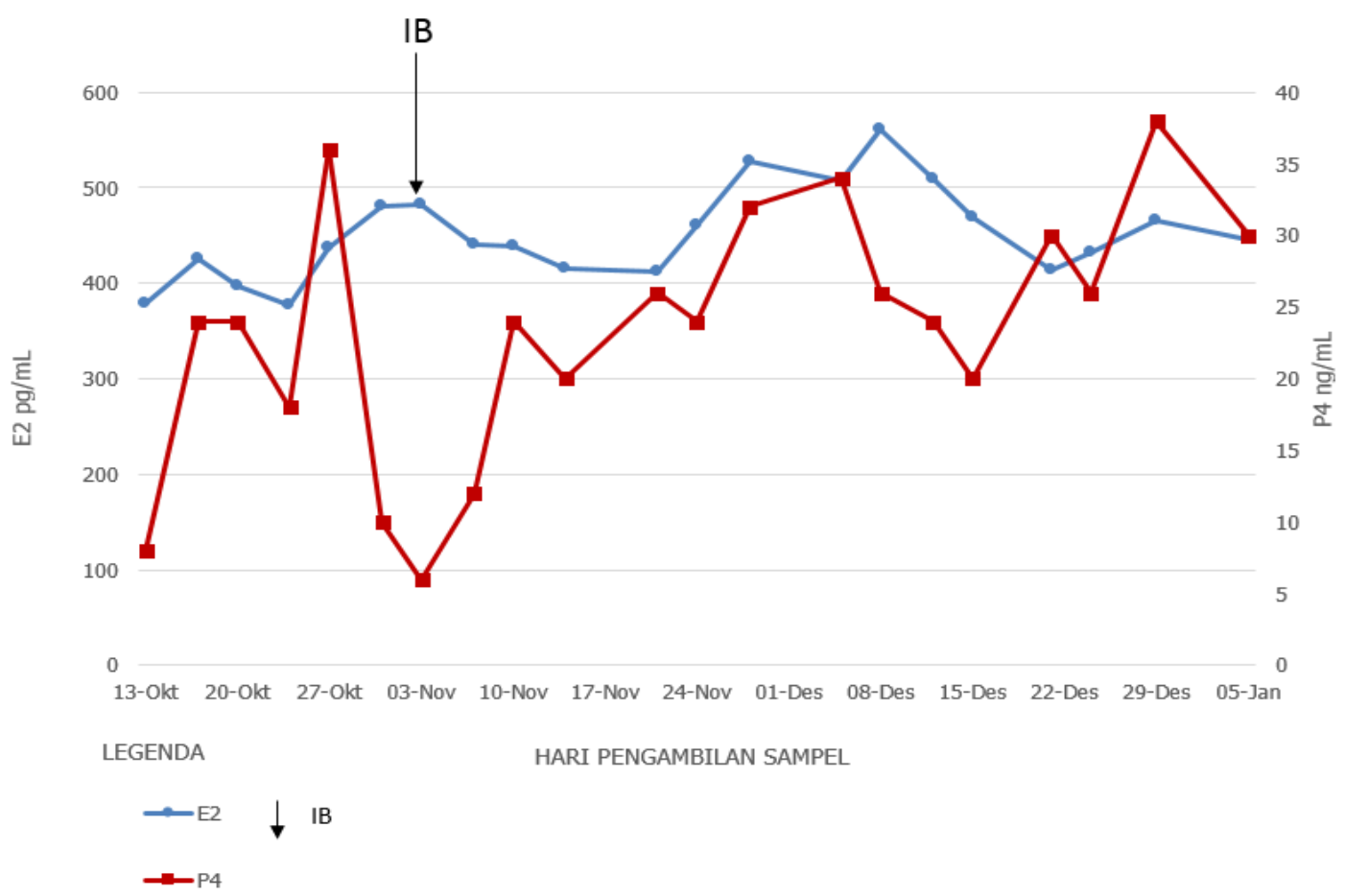

Gambar 7 Gambaran hormon progesteron dan esterogen sapi \#020 siklus dan bunting

dalam penelitian sapi perah, Drh. Dedi Rahmat Setiadi M.Si serta Drh. Mokhamad Fakhrul Ulum M.Si yang banyak membantu selama penelitian dilapang maupun di laboraturium dan kepada bapak Harisman dan bapak Asep Kartiyana sebagai paramedis yang ada dilapang. Terimakasih pula kepada PT Agroprima Lab atas penggunaan alat ultrasonografi (4VetMini, dan i-Scan Draminski) dalam penelitian ini, serta beasiswa unggulan DIKTI yang telah mensponsori sebagian penelitian ini.

"Penulis menyatakan tidak ada konflik kepentingan dengan pihak-pihak yang terkait dalam penelitian ini"

\section{DAFTAR PUSTAKA}

Ayalon, N. 1978. A review of embryonic mortality in cattle. J. Reprod. Fertil.54:483-493.

Beal W, Perry R, Corah L, 1992. The use of ultrasound in monitoring reproductive physiology of beef cattle. Journal of animal science 70, 924-929.

Cameron A, Malmo J. 1993. Evaluation of an ultrasonic Doppler probe for pregnancy diagnosis in cattle. Australian veterinary journal70, 109-111.
Cartmill JA, Hensley BA, El-zarkounySZ,RozellTG, SmithJF and StevensonJS. 2001. Stage of cycle, incidence and timing ofovulation, and pregnancy rates in dairy cattle after three timed breeding protocols. J. DairySci. 84: 1051-1059.

Curran S, Pierson R, Ginther O. 1986. Ultrasonographic appearance of the bovine conceptus from days 20 through 60 . Journal of the American Veterinary Medical Association 189, 1295-1302.

El-Zarkouny SZ, Cartmill JA, Hensley BA, and Stevenson JS. 2000. Progesterone increases pregnancy rates and embryo survival in lactating dairy cows. Journal Dairy Science. 83(Suppl. 1):217 (Abstr.).

Ferguson JD, Gallian DT, Thomsen N. 1994. Principal Description of Body Condition Score in Holstein Cows. J.Dairy Science. 77: 2695-703.

Forde N, Beltman M E, Duffy G B, Duffy P, Mehta J P, PO'Gaora J F, Roche P, Lonergan, and M. A. Crowe. 2011. Changes in the endometrial transcriptome during the bovine estrous cycle: Effect of low circulating progesterone and consequences for conceptus elongation. Biol. Reprod. 84:266-278.

Green JA, Parks TE, Avalle MP, Telugu BP, McLain AL, Peterson AJ, McMillan W, Mathialagan N, Hook RR, Xie S. 2005. The establishment of an ELISA for 
the detection of pregnancy-associated glycoproteins (PAGs) in the serum of pregnant cows and heifers. Theriogenology63, 1481-1503.

Kähn W, Volkmann D. 2004. Veterinary reproductive ultrasonography. Schlütersche.

Markusfeld O, Adler H, Nahari N, Kastner D. 1990. A routine 20-22 days postservice milk progesterone monitoring in dairy cows. Economic evaluation. British Veterinary Journal 146, 504-508.

Oltenacu PA, Ferguson JD, Lednor AJ .1990. Economic Evaluation of Pregnancy Diagnosis in Dairy Cattle: A Decision Analysis Approach. Journal of Dairy Science 73:2826-2831.

Pereira R, Caixeta L, Giordano J, Guard C, Bicalho R. 2013. Reproductive performance of dairy cows resynchronized after pregnancy diagnosis at 31 ( \pm 3 days) after artificial insemination ( $\mathrm{Al}$ ) compared with resynchronization at 31 ( \pm 3 days) after Al with pregnancy diagnosis at 38 ( \pm 3 days) after Al. Journal of Dairy Science 96, 7630-7639.

Romano JE, Thompson JA, Kraemer DC. Wethusin ME, Forrest DW, Tomaszweski MA. 2006. Early pregnancy diagnosis by palpation per rectum:Influence on embryo/fetal viability in dairy cattle. Theriogenology 67 (2007) 486-493.

Sayuti A, Herrualfin, Armansyah T, Syafruddin, dan Siregar Tongku N. 2011.Penentuan Waktu Terbaik Pada Pemeriksaan Kimia Urin Untuk Diagnosis Kebuntingan Pada Sapi Lokal. Jurnal Kedokteran Hewan. Vol.5 No.1

Scully S, Butler S, Kelly A, Evans A, Lonergan P, Crowe
M. 2014. Early pregnancy diagnosis on days 18 to 21 postinsemination using high-resolution imaging in lactating dairy cows. Journal of Dairy Science 97, 3542-3557.

Simersky R, Swaczynova J, Morris DA, Franek MM, Strna TRNAD. 2007. Development of

an ELISA-based kit for the on-farm determination of progesterone in milk. Veterinarni Medicina 52(1): $19-28$

Sreenan JM, Diskin MG. 1986. The Extent and Timing of Embryonic Mortality in the Cow, In: Sreenan JM, Diskin MG (Eds.) Embryonic Mortality in Farm Animals. Springer Netherlands, pp. 1-11.

Stevenson JS. 2001. Reproductive Management of Dairy Cows in High Milk-Producing Herds. J. Dairy Sci. 84(E.Suppl.):E128-E143.

Tjiptosumirat T, TuasikalBJ, Lelananingtyas N. 2004. Rdioimmunoassay (ria) Progesteron untuk Diagnosis Kegagalan Inseminasi Buatan pada Ternak Sapi Perah. Prosiding Presentasi Ilmiah Keselamatan Radiasi dan Lingkungan $X$, Puslitbang Keselamatan Radiasi dan Biomedika Nuklir, BATAN, (2004), hal: 159 - 171

Vanroose G, A De Kruif, A Van Soom, M Forsberg, T Greve, $\mathrm{H}$ Gustafsson, $\mathrm{T}$ Katila, $\mathrm{H}$ Kindahl and $\mathrm{E}$ Ropstad. 2000. Embryonic mortality and embryophatogeninteractions. Anim. Rep. Sci. 60-61: 131143.

Wijono DB. 1998. Peran Kadar progsteron Dalam Plasma Darah untuk Deteksi Estrus dan Aktivitas Ovarium. seminar Nasional Peternakan dan Veteriner Tahun 1998. 